\title{
ANALISIS TINGKAT KEPUASAN PENGGUNA LANGSUNG DAN TIDAK LANGSUNG TERHADAP APLIKASI SUATU SISTEM INFORMASI
}

\author{
Agus Sulaiman \\ Alumnus, Program Magister Manajemen Universitas Bunda Mulia, Jakarta
}

\begin{abstract}
:
Information system is becoming much more important for a company to gain competitive advantage compared to their competitors. A company with good information systems will acquired better opportunity. The purpose of this study is to understand the satisfaction level of an information system application and factors that influenced the user satisfaction. Factors that have been tested are system speed, system security, system accuracy, effectiveness and efficiency, IT Support and user friendliness. This study was taken place in PT X that uses an IS application to support company business. The result shows that users are satisfied to the current application. There are three factors that significantly influence user satisfaction: system accuracy, system speed, and IT support. On the contrary, factors that have not significantly influencing user satisfaction of information system are system security, effectiveness and efficiency, and user friendly. Some actions must be taken such as repairing system speed from hardware site, software development, and networking reliability. Next module to be developed is Fixed Asset Module, based on the readiness of accounting division.
\end{abstract}

Keywords: information systems, user satisfaction, application

\section{PENDAHULUAN}

Dewasa ini, tidak sedikit perusahaan bergerak di industri lensa kacamata telah menerapkan aplikasi sistem informasi untuk dapat mempertahankan keunggulan konpetitifnya (competitive advantage). Oleh karena itu sebuah perusahaan yang memiliki sistem informasi yang terintegrasi dengan proses bisnisnya secara baik akan memenangkan persaingan dengan perusahaan yang memiliki sistem informasi lebih lemah. Sistem informasi yang dipakai biasanya menggunakan database clipper dan fox pro yang dikembangkan sekitar tahun 1996. Seiring dengan perkembangan teknologi, maka sistem yang diterapkan sudah tidak dapat menunjang proses bisnis yang begitu cepat berkembang. Oleh karena itu sisem informasi yang baru dikembangkan sejak tahun 2005 dengan menggunakan database oracle, disini terjadi pro dan kontra oleh pihak user dalam tahap implementasi, sehingga pihak manajemen ingin menjustifikasi dan mengevaluasi sistem yang dikembangkan apakah sudah sesuai dengan kebutuhan perushaan dan sampai sejauh mana tingkat kepuasan pemakainya.

\section{TUJUAN DAN MANFAAT PENELITIAN}

Penelitian ini dilakukan atas beberapa pertimbangan, yaitu::

1. mengetahui sejauh mana tingkat kepuasan pemakai secara langsung maupun tidak langsung terhadap modul aplikasi sistem informasi di PT. X;

2. untuk perusahaan yang bergerak dalam bidang pengembangan sistem informasi, penelitian ini akan berguna sebagai referensi dalam melakukan metode evaluasi penggunaan aplikasi sistem informasi. 


\section{TINJAUAN TEORITIS}

\section{Pengertian Sistem Informasi}

Menurut Raymond Mcleod, Jr (1996) sistem dapat diartikan sebagai sekelompok elemen yang terintegrasi dengan maksud yang sama untuk mencapai suatu tujuan, sedangkan informasi adalah data yang telah diolah atau diproses sehingga data tersebut memiliki arti.

Menurut Davenport (1998), sistem informasi adalah sekumpulan subsistem yang terdefinisi berdasarkan fungsional atau organisasi, yang membantu pengambilan keputusan dan mengontrol organisasi dengan menggunakan teknologi informasi untuk menangkap, menyebarkan, menyimpan, menerima, memanipulasi atau mempertunjukkan informasi yang dipakai dalam satu atau lebih proses bisnis

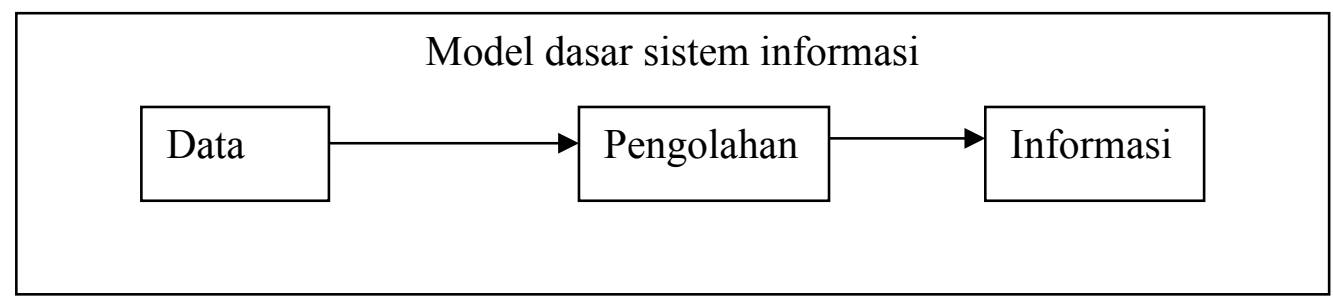

Gambar 1. Model dasar sistem informasi (Davenport, 1998)

\section{Fungsi Sistem Informasi}

Menurut Robert C. Nickerson (2001) fungsi dari sistem informasi terdiri dari empat bagian penting yaitu fungsi input (input function), fungsi penyimpanan (storage function), fungsi proses (processing function), fungsi keluar (output function)

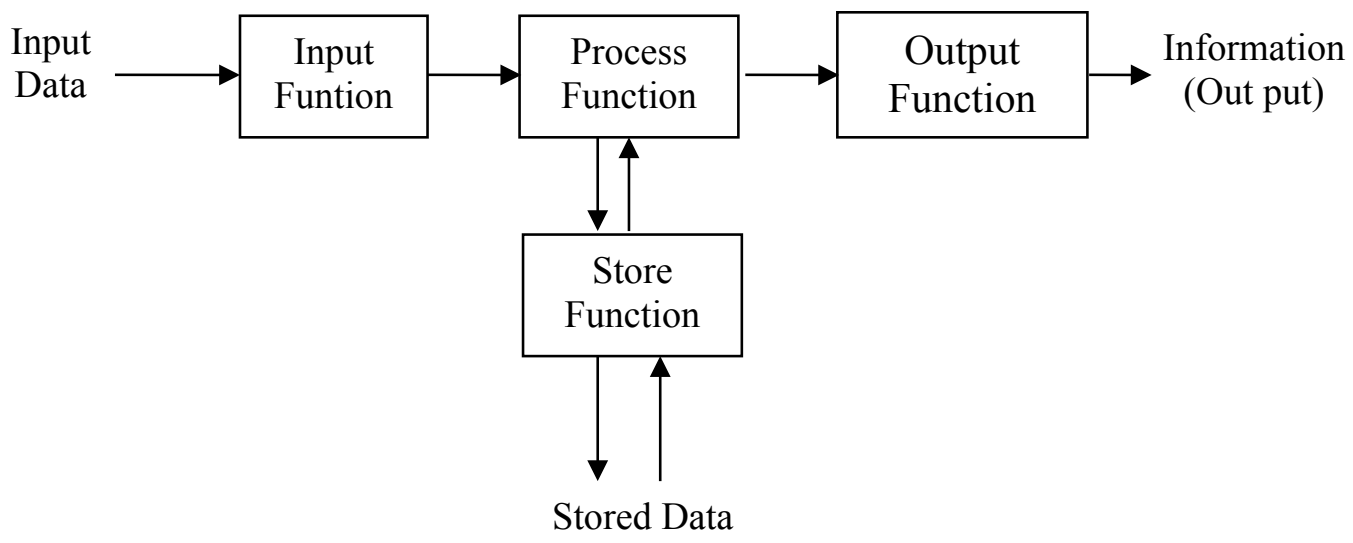

Gambar :The Funcion of an information system (Robert C. Nickerson, 2001)

\section{Pengguna Sistem Informasi}

Para pengguna informasi dalam suatu organisasi atau perusahaan dapat dibagai menjadi beberapa kelompok yaitu manajer, non manajer dan orang-orang atau organisasiorganisasi dalam lingkungan perusahaan. 
Pada saat merancang sistem informasi, penting sekali untuk mempertimbangkan posisi manajer di dalam tingkatan manajemen karena hal ini sangat mempengaruhi sumber informasi dan cara penyajiannya.

Tingkat Perencanaan Strategis

Tingkat Pengendalian Manajemen

Tingkat Pengendalian Operasional

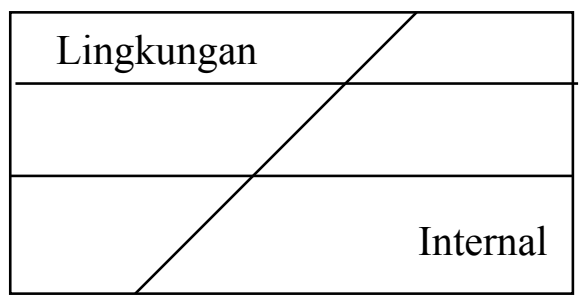

A. Pengaruh pada Sumber Informasi

Tingkat Pengendalian Strategis

Tingkat Pengendalian Manajemen

Tingkat Pengendalian Operasional

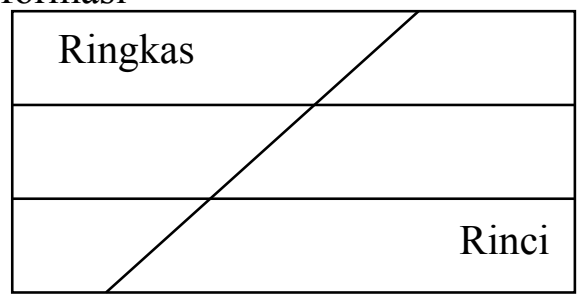

B. Pengaruh pada Bentuk Informasi

Pada gambar diatas menunjukkan bahwa para manajer pada tingkat perencanaan strategis (bagian atas) lebih menekankan informasi lingkungan daripada manajer ditingkat lebih bawah, dan para manajer di tingkat pengendalian operasional menganggap informasi internal sebagai yang paling penting, sedangkan para manajer pada tingkat perencanaan strategis memilih informasi dalam bentuk ringkasan daripada manajer di tingkat lebih bawah, sedangkan para manajer di tingkat pengendalian operasional lebih memilih informasi dalam bentuk rinci.

Menurut Rober C Nickerson (2001) pengguna sistem informasi dapat dibagi menjadi 2 kelompok yaitu pengguna langsung (direct user) dan pengguna tidak langsung (indirect user). Pengguna langsung merupakan user yang berhubungan secara langsung denga aplikasi sistem informasi seperti dalam hal penginputan data dan melakukan evaluasi laporan dari hasil aplikasi sistem informasi. Sedangka pengguna tidak langsung adalah pengguna yang secara tidak langsung berhubungan dengan aplikasi sistem informasi seperti beberapa manajer yang meminta laporan dari bawahannya yang dicetak pada kertas yang dihasilkan dari aplikasi sistem informasi.

\section{Kepuasan Pengguna}

Menurut Stanton (1994), tingkat kepuasan konsumen ditentukan dengan membandingkan hasil yang diharapkan dari suatu produk atau jasa dengan hasil berdasarkan pengalaman dengan mengkonsumsi produk atau jasa tersebut. Hasil yang sama merupakan kepuasan dari konsumen, tetapi jika hasil yang diperoleh sangat sedikit dari yang diharapkan hal itu merupakan bentuk ketidakpuasan konsumen.

Sedangkan menurut Kotler (2002), kepuasan pengguna dapat didefinisikan sebagai suatu tingkat perasaan seorang pengguna sebagai hasil perbandingan antara harapan pengguna tersebut akan sebuah produk dengan hasil nyata yang diperoleh si pengguna dari produk 
tersebut. Jika kinerja produk memenuhi ekspetasi dari konsumen maka tingkat kepuasan konsumen adalah tinggi, sedangka jika kinerja produk tidak dapat memenuhi ekspetasi konsumen maka tingkat kepuasan konsumen akan rendah. Seandainya hasil yang diperoleh melebihi harapan, tentu pengguna akan merasa sangat puas (highly satisfied)

\section{METODOLOGI PENELITIAN}

Dalam melakukan penelitian ini menggunakan model analisis kuantitatif yang merupakan penelitian terhadap masalah-masalah berupa fakta-fakta yang menggambarkan keadaan objek penelitian pada saat sekarang yang dapat digunakan untuk menarik kesimpulan atas masalah-masalah penelitian.

\section{Objek Penelitian}

Penelitian dilakukan pada PT. X, sebuah perusahaan manufaktur yang bergerak dalam bidang lensa kacamata yang berlokasi di Jakarta. Penelitian dilakukan pada bagian produksi dan pembelian

\section{Teknik Pengumpulan Data}

Data diperoleh dengan melakukan survei dan menyebarkan kuesioner mengenai tingkat kepuasan pemakai langsung dan tidak langsung terhadap aplikasi system.

Teknik skala yang digunakan dalam penelitian adalah skala nominal dan skala ordinal (Likert Scale), untuk skala ordinal digunakan untuk menentukan tingkat kepuasan pemakai sistem informasi atau ketidakpuasan pemakai sistem informasi. Pemberian bobot nilai dari masing-masing jawaban ditentukan sebagai berikut :

- 1 = sangat tidak setuju (STS)

- 2 = tidak setuju (TS)

- $3=$ netral $(\mathrm{N})$

- 4 = setuju (ST)

- 5 = sangat setuju (SS)

\section{Variabel Penelitian}

Dalam penelitian ini dilakukan analisis terhadap tingkat kepuasan penggunaan akan aplikasi sistem informasi dan menguji hubungan antara beberapa faktor yang diduga akan mempengaruhi kepuasan pengguna (dependent variable), sedangkan faktor-faktor lain yang dianggap sebagai variable bebas (independent variable) adalah :

- Kecepatan sistem (system speed)

- Keamanan sistem (system security)

- Ketepatan sistem (system accuracy)

- Efektif dan efisiensi (effectiveness and efficiency)

- Dukungan IT (IT support)

- Kemudahan Pemakai (user friendliness)

\section{Hipotesis}

Pengujian hipotesis dalam penelitian ini terbagi menjadi 2 bagian yaitu yang pertama menguji tingkat kepuasan pemakai sistem informasi, dan kedua mengenai hubungan antara beberapa faktor yang diduga mempunyai hubungan dengan faktor kepuasan pengguna sistem informasi 


\section{TEMUAN DAN PEMBAHASAN}

Hasil penelitian yang dilakukan dengan menggunakan analisis deskriptif, dari hasil analisis tersebut bahwa rata-rata kinerja variable bebas yang paling tinggi adalah variabel kemudahan pemakai sebesar $81,40 \%$. Sedangkan rata-rata kinerja variable bebas yang paling rendah adalah variabel efektifitas dan efisiensi sebesar 68,20\%. Bila dilihat secara keseluruhan maka nilai rata-rata variabel bebas berada pada range 68,20\% sampai $81,40 \%$. Untuk lebih jelasnya dapat dilihat pada tabel rata-rata dari variabel bebas berdasrkan nilai rata-rata tertinggi

Tabel 1 : Rata-rata variabel bebas berdasarkan nilai

Rata-rata tertinggi

\begin{tabular}{|l|l|c|c|}
\hline No & \multicolumn{1}{|c|}{ Variabel } & \multicolumn{2}{c|}{ Nilai rata-rata } \\
\hline 1. & Kemudahan Pemakaian & 4,07 & $81,40 \%$ \\
\hline 2. & Keamanan Sistem & 3,94 & $78,80 \%$ \\
\hline 3. & Ketepatan Sistem & 3,86 & $77,20 \%$ \\
\hline 4. & Dukungan IT & 3,75 & $75,00 \%$ \\
\hline 5. & Kecepatan Sistem & 3,46 & $69,20 \%$ \\
\hline 6. & Efektifitas dan Efisiensi & 3,41 & $68,20 \%$ \\
\hline
\end{tabular}

Rata-rata kepuasan pemakai per bagian pekerjaan yang paling tinggi adalah bagian persediaan (inventory) dan administrasi sebesar $81,60 \%$. Sedankan rata-rata kepuasan pemakai per bagian pekerjaan paling rendah adalah piutang (account receivable) yaitu sebesar $69,40 \%$. Bila dilihat secara keseluruhan maka nilai rata-rata kepuasan pemakai per bagian pekerjaan berapa pada range $69,40 \%$ sampai $81,60 \%$. Untuk tingkat kepuasan pemakai perlevel struktur organisasi yang paling tinggi berada dilevel manajerial sebesar $90 \%$, sedangkan rata-rata kepuasan pemakai per level struktur organisasi paling rendah adalah dilevel supervisor sebesar 74,60\%. Untuk rata-rata kepuasan pemakai per tingkat pendidikan yang paling tinggi adalah diploma $77,80 \%$, sedangkan rata-rata kepuasan pemakai pertingat pendidikan paling rendah adlah dilevel sarjana 75.40. Bila dilihat secara keseluruhan, maka nilai rata-rata kepuasan pemakai pertingkat pendidikan berada pada range $75,40 \%$ sampai $77,80 \%$

\section{KESIMPULAN DAN SARAN}

Dari hasil penelitian ini maka dapat disimpulkan bahwa :

1. Pengguna tidak langsung aplikasi sistem informasi merasa lebih puas dibandingkan dengan pengguna langsung aplikasi sistem informasi.

2. Tiga faKtor yang mempengaruhi secara signifikan kepuasan pemakai aplikasi sistem informasi yaitu ketepatan sIstem (system accuracy), kecepatan sIstem (system speed) dan dukungan IT (IT support).

3. Tiga faKtor yang tidak mempengaruhi secara signifikan kepuasan pemakai aplikasi sistem informasi yaitu keamanan sIstem (system security), efektifitas dan efisiensi (effectiveness and efficiency) serta kemudahan pemakai (user friendliness).

Untuk penelitian selanjutnya sangat terbuka untuk dilakukan pendalaman mengenai : 
1. Apakah terdapat indikasi bahwa semakin user berinteraksi dengan sistem maka ia akan cenderung semakin merasa tidak puas.

2. Apakah faktor dari keamanan system (system security), efektifitas dan efesiensi (effentiveness and efficiency) serta kemudahan pemakai (user friendliness) bila diuji pada perusahaan lain yang menerapkan sistem informasi akan menghasilkan hasil yang sama pada penelitian ini.

3. Adakah faktor lain yang dapat mempengaruhi kepuasan pemakai sistem informasi dalam tahap implementasi.

\section{DAFTAR RUJUKAN}

Loudon, David L. and Albert J. Della Bitta, Consumer Behaviour, McGraw-Hill, Singapore, 1993

Indrajit, Richardus Eko, Pengantar Konsep Dasar Manajemen Sistem Informasi dan Teknologi Informasi, PT. Elex Media Komputindo, Jakarta, 2001

O’Brien, James A., Introduction to Information System, McGraw-Hill, New York, 2005

Mcleod, Raymond, Jr. Sistem Informasi Manajemen, PT Prenhallindo, Jakarta, 1996

Nickerson, Robert C, Business and Information Systems, Prentice Hall, 2001

Remenyi, Dan, Arthur Money, and Alan Twite, Effective Measurement and Management of IT Costs and Benefits, Butterwoth-Heinemann Ltd, Oxford, 1995

Kotler, Philip, Marketing Management, Prentice Hall, New Jersey, 2002

Stanton, William J., Michael J. Etzel, Bruce J. Walker, Fundamental of Marketing, Mc Graw-Hill, Singapore, 1994

Supranto, J., Statistik Teori dan Aplikasi, Erlangga, Jakarta, 2001

Purwanto, Suharyadi, Statistika untuk Ekonomi dan Keuangan Modern, Salemba Empat, Jakarta , 2004

Sudarmanto, R. Gunawan, Analisis Regresi Linear Ganda Dengan SPPS, Graha Ilmu, Yogyakarta, 2005

Sugiyono, Metodologi Penelitian Bisnis, CV Alfabeta, Bandung, 1999 